(Uniwersytet Warszawski, e-mail: m.falkowska@uw.edu.pl)

ORCID: 000-0002-5059-1182

\title{
JAKI JEST EMPATYCZNY LEKARZ? OBRAZ EMPATII LEKARZA W OPINIACH ZAMIESZCZONYCH W PORTALU ZNANYLEKARZ.PL
}

\section{WPROWADZENIE: CEL PRACY, PODSTAWA MATERIALOWA}

Celem mojej pracy jest próba ustalenia, jaki obraz empatycznego lekarza wyłania się $z$ zamieszczonych w Internecie opinii pacjentów oraz jakie aspekty zachowania lekarza interpretowane sa jako komunikujacce empatię badź jako skorelowane $z$ nastawieniem empatycznym wobec pacjenta. Artykul, choć rozpatruje zagadnienie empatii z perspektywy jezzykoznawczej, wpisuje się tym samym w intensywną dyskusję prowadzona w przestrzeni nauk medycznych i nauk o zdrowiu, a skoncentrowaną m.in. wokół różnych sposobów rozumienia i modelowania pojęcia <empatia> na użytek medycyny [Ziółkowska-Rudowicz, Kładna 2014; Wilczek-Rużyczka 2017], stosowania właściwych technik komunikacji [Rosenberg, Molho 1998; Doroszewski i in. 2014; Baranowska, Doroszewska 2018] czy sposobów przekazywania niepomyślnych diagnoz [Baile i in. 2000; Jankowska 2014].

Przedstawiona w artykule analiza semantyczna powstała na podstawie korpusu skonstruowanego za pomoca narzędzia Sketch Engine [Kilgarriff $i$ in. $2014^{1}$ ], dzięki któremu pobrałam $z$ portalu ZnanyLekarz.pl pliki zawierające wystapienia form fleksyjnych rzeczownika empatia lub przymiotnika empatyczny. Podstawowe dane ilościowe na temat korpusu przedstawia poniższa tabela:

Tabela 1. Informacje o korpusie

\begin{tabular}{|l|r|}
\hline Tokeny & 1033861 \\
\hline Słowa & 859862 \\
\hline Pliki & 908 \\
\hline
\end{tabular}

${ }^{1}$ Chciałabym wyrazić wdzięczność dr hab. Agnieszce Leńko-Szymańskiej, koordynatorce do spraw Sketch Engine na UW, za cenna pomoc w opanowaniu obsługi oprogramowania. 
ZnanyLekarz.pl to serwis internetowy gromadzacy dane na temat osób reprezentujących szeroko rozumiane zawody medyczne (m.in. lekarzy specjalistów, stomatologów, psychologów, rehabilitantów, dietetyków, terapeutów, a także weterynarzy ${ }^{2}$ ), umożliwiający użytkownikom wyszukiwanie lekarzy i placówek medycznych, umawianie wizyt, a także publikowanie opinii na temat poszczególnych lekarzy. ${ }^{3}$ Zgodnie $z$ regulaminem portalu opinie pacjentów moga być oparte jedynie na prawdziwych, indywidualnych doświadczeniach zwiazanych $z$ wizyta $u$ danego specjalisty; komentarze użytkowników podlegaja moderacji. Zgromadzony na potrzeby analizy materiał składa się w przeważającej części $z$ opinii pacjentów na temat poszczególnych lekarzy. ${ }^{4}$ Jak pokazał przegląd konkordancji dla rzeczownika empatia, przykłady zawierajace formy tego słowa w przeważającej większości pochodziły $z$ opinii o charakterze pozytywnym, znaleziono jedynie kilka opinii negatywnych oraz kilka przykładów pochodzących $z$ autocharakterystyki umieszczonej w portalu przez samego lekarza. W zwiazku $z$ tym, że skupiam się tu na perspektywie pacjenta, ostatnią kategorię danych zdecydowałam się wyłączyć $z$ dalszej analizy. Należy zaznaczyć, że choć opinie składające się na materiał badawczy sa publicznie dostępne w Internecie, ze względów etycznych $z$ cytowanych w niniejszym opracowaniu fragmentów usunęłam wszelkie dane osobowe lekarzy i podpisy autorów opinii. ${ }^{5}$

Warto podkreślić, że relatywnie nowy, choć ekspansywny we współczesnej polszczyźnie, rzeczownik empatia (jak i derywowany od niego

2 Ze świadomościa różnic między specyfiką pracy reprezentantów poszczególnych zawodów medycznych w toku dalszych rozważań dla oszczędności miejsca najczęściej będę posługiwać się uogólnioną etykietą lekarz. Nie będę także przywoływać opinii odnoszacych się do pracy weterynarzy, ponieważ w tym wypadku trudno jest niekiedy jednoznacznie przesądzić, czy empatia lekarza odnosi się przede wszystkim do zwierzęcego pacjenta, czy raczej do opiekuna zwierzęcia, czy też aktywowana jest w obu tych relacjach.

${ }^{3}$ Leksykalne wyznaczniki wartościowania obecne $\mathrm{w}$ opiniach zamieszczanych w portalu ZnanyLekarz.pl opisała Marta Woźniak [2021].

4 Konkordancję dla rzeczownika empatia poddałam anotacji, która miała pokazać, w odniesieniu do których specjalności autorzy opinii najczęściej używaja słowa empatia. Największa grupę stanowiły opinie dotyczące ginekologów i położników (233 z 817 użyć rzeczownika empatia), następnie stomatologów (166), psychologów (51), psychiatrów (31) oraz lekarzy rodzinnych i internistów (27). Dane te traktuję wyłącznie pomocniczo, warto jednak zauważyć, że nie pokrywają się one $z$ ustaleniami badaczy, którzy analizowali wskaźniki poziomu empatii u lekarzy różnych specjalności [m.in. Kliszcz 2015; Królak 2017]. Joanna Kliszcz wskazuje, że „na dynamikę poziomu empatii ma wpływ płeć i wiek respondentów, a nie miejsce i charakter pracy" [Kliszcz 2015, 123].

5 Postępuję w tym miejscu zgodnie $z$ wytycznymi dotyczącymi etycznych aspektów badań Internetu [Frantzke i in. 2020, 10-11]. Cytaty podaję w ich oryginalnej (choć najczęściej skróconej) formie, bez ingerencji korektorskich. Wszelkie wyróżnienia w cytatach pochodzą ode mnie. 
przymiotnik) w próbce dyskursu będącego przedmiotem mojego zainteresowania odgrywa wyraźnie istotniejszą rolę niż w polszczyźnie ogólnej. Wskazuje na to choćby porównanie frekwencji względnej lematów EMPATIA i EMPATYCZNY w zgromadzonym korpusie i w danych Narodowego Korpusu Języka Polskiego (NKJP, podkorpus zrównoważony). ${ }^{6}$

Tabela 2. Liczba wystąpień i frekwencja względna rzeczownika EMPATIA i przymiotnika EMPATYCZNY

\begin{tabular}{|l|c|c|c|}
\hline \multicolumn{1}{|c|}{ Lemat } & $\begin{array}{c}\text { Liczba poświadczeń } \\
\text { w korpusie }\end{array}$ & $\begin{array}{c}\text { Frekwencja względna } \\
\text { w korpusie }\end{array}$ & $\begin{array}{c}\text { Frekwencja } \\
\text { względna w NKJP }\end{array}$ \\
\hline EMPATIA & 817 & 790 & 2,86 \\
\hline EMPATYCZNY & 972 & 940 & 0,69 \\
\hline
\end{tabular}

To ogólne wyliczenie obrazuje, jak sądzę, istotność samej kategorii 'empatii' w analizowanym typie tekstu oraz jej wagę dla subiektu wartościowania - dla pacjenta.

\section{MIEJSCE EMPATII WŚRÓD KOMPETENCJI LEKARZA}

Zgromadzony materiał dość wyraźnie pokazuje przekonanie pacjentów, że choć empatia jest ważna i cenioną umiejętnością lekarza, to na pewno nie może zastapić wiedzy specjalistycznej i umiejętności zawodowych. Na to postrzeganie empatii w hierarchii pożądanych cech lekarza wskazuja zawarte $\mathrm{w}$ korpusie typowe połaczenia wyrazowe: $\mathrm{n}$-gramy ${ }^{7}$ i kolekcje. ${ }^{8}$

Na liście n-gramów liczacych od 3 do 5 elementów składowych i zawierających formę rzeczownika empatia pierwsze miejsce pod względem frekwencji zajmuje połączenie profesjonalizm $i$ empatia (78 wystapień). Kolejność, w której pojawiaja się te określenia, nie wydaje się przypadkowa - wiele opinii jest strukturyzowanych właśnie w taki sposób, aby

6 Zestawiam tu jedynie frekwencję względna (tj. liczbę wystapień na milion słów w danym zbiorze), ponieważ wspomniane dwa typy danych pod innymi istotnymi względami (np. czasu powstania, typu funkcjonalnego tekstu) sa zbyt różne, aby można je było odpowiedzialnie porównywać.

7 Rozumiane tu zgodnie ze znaczeniem przypisywanym temu terminowi w Sketch Engine, tj. jako sekwencje określonej liczby tokenów współwystępujących w określonym porządku w tekście.

8 Termin kolekcja stosuję za J. Bartmińskim i S. Niebrzegowską-Bartmińską [2009, 180] w odniesieniu do stosowanych przez nadawcę wyliczeń: sekwencji wyrazów sąsiadujących ze sobą w danym tekście, pozostających w relacji apozycji lub koniunkcji. $Z$ wprowadzonych definicji wynika, że niektóre kolekcje moga znaleźć się na liście n-gramów. 
przede wszystkim wskazać wiedzę lekarza i jego ściśle zawodowe kompetencje, a dopiero na drugim planie umieścić empatyczność. Por.:

(1) Pani doktor wraz $z$ innymi pracownikami podeszli w pełni profesjo nalnie i rzeczowo, przy tym z empatia.

(2) Wysoko oceniany profesjonalizm, podejście do pacjenta z odczuwalna wysoka empatia oraz kultura osobista sprzyjaja procesowi leczenia i buduja pozytywne nastawienie do terapii.

(3) Pani doktor posiada duża wiedza medyczna popartą doświadczeniem i empatię, która jest równiéz bardzo istotna.

(4) Uważam, że Pani Doktor łączy w sobie olbrzy mią wiedzę merytoryczna oraz ogrom empatii i podejścia do pacjenta co w tym zawodzie myśle jest równie ważne.

(5) (...) ma ogromna wiedzę medyczna i kompetencje ale do tego także empatię.

(6) Uosobienie profesjonalizmu i empatii do tego delikatna reka i cierpliwość.

(7) Wspaniały lekarz, z bardzo dużą wi ed za i doświadczeni e m odznaczajacy się dodatkowo empatia i wysoką kulturą osobista.

W wypowiedziach tych widać, że ocena lekarza formułowana $z$ perspektywy pacjenta jest co najmniej dwuaspektowa. Najistotniejszym kryterium oceny sa kompetencje ściśle zawodowe (por. profesjonalizm, wiedza medyczna, wiedza merytoryczna, kompetencje) przypisywane lekarzowi, podejście do pacjenta oceniane jest w drugiej kolejności, o czym świadczy szyk enumeracji, ale także językowe wyznaczniki hierarchizacji treści wypowiedzi, typu przy tym, do tego, również, także, dodatkowo. W korpusie można oczywiście znaleźć także konteksty, w których empatia lekarza wymieniana jest na pierwszym miejscu, przed informacja o kompetencjach zawodowych, ale sa to pojedyncze przykłady, por.:

(8) Pani doktor (...) to wyjątkowa osoba o niesamowitej e m patii, u waż no ści i wiedzy.

(9) Empatia i kompetencja Pani Doktor na najwyższym poziomie.

(10) Miałem kontakt $z$ wieloma lekarzami i uważam że pan dr. jest godny polecenia przede wszystkim ze względu naswoja empatię oraz zasób wiedzy który posiada.

Empatyczność lekarza jest przez pacjentów doceniana tym bardziej, że wciąż nie jest postrzegana jako standardowa cecha osób wykonujących zawody medyczne, jako postawa praktykowana powszechnie, ale raczej jako wyjątkowy osobisty walor konkretnej osoby, por.:

(11) Miałem kontakt $z$ wieloma lekarzami i uważam że pan dr. jest godny polecenia przede wszystkim ze względu na swoja e m patię oraz zasób wiedzy który posiada.

(12) Jeden z nielicznych lekarzy jakich spotkałam na swojej drodze (a było ich wielu), który jest zainteresowany zdrowiem pacjenta i naprawdę chce pomóc. Lekarz o wysokiej kulturze osobistej i empatii do pacjenta. 
(13) Lekarz zrozumiał mój problem i bardzo mi pomógł, okazał empatię. C oś c z e go dawno nie odczułem w kontaktach z lekarzami.

(14) To co wyróżnia Panią doktor spośród wielu znanych mi lekarzy to uśmiech, ciepło, cierpliwość i ogromna empatia, które sa równie ważne jak wiedza i fachowość i zapewniaja poczucie bezpieczeństwa.

Autorzy przytoczonych opinii sugeruja, że empatia w zawodach medycznych nie ma charakteru systemowego - spotkanie lekarza cechującego się empatia jest ich zdaniem rzadkością. Na podobny aspekt postrzegania lekarskiej empatii wskazuja najczęstsze przymiotnikowe kolokacje rzeczownika empatia, za sprawa których pacjenci nie tylko po prostu kwalifikuja poziom empatii danej osoby jako wysoki (por. duża, olbrzymia, wielka, ogromna, wysoka empatia), ale także za pomoca doboru jednostek leksykalnych sygnalizuja, że jest to poziom zaskakujacy, ponadstandardowy - taki, jakiego się nie spodziewali (np. niezwykła, niewyobrażalna, niesamowita empatia), por. np.:

(15) Profesjonalne podejście do pacjenta nacechowane nies potykana e m patia (szczególnie w trudnym okresie początkowej pandemii covid-19).

(16) Na podkreślenie zasługuje nie zwykła e mpatia, fachowość i zrozumienie problemu zdrowotnego pacjenta i zaufanie jakie budzi pani dr (...).

(17) Miałem przyjemność być pacjentem Pani Dr. (...), która cechuje ni e w y o b ra$\dot{z}$ alna e mpatia w stosunku do pacjenta oraz niesamowity profesjonalizm.

Jak widać, przy okazji opisywania empatii wybranych lekarzy, autorzy opinii w sposób pośredni lub bezpośredni zarysowuja tło, na którym sytuują oceniana osobę. Odnosza się także niekiedy do funkcjonowania całego systemu opieki zdrowotnej w Polsce, por.:

(18) Lekarz z ogromna wiedza, profesjonalnym podejściem, oprócz tego bardzo empatyczna Osoba. Gdyby było więcej takich Osób Lekarzami, to Służba Zdrowia w Polsce byłaby na bardzo wysokim pozio$\mathrm{mie.}$

(19) (...) tacy lekarze jak doktor (...) to „ginacy gatunek”. Teraz licza się sterylne białe wnętrza i orchidee na rejestracjach a nie doświadczenie, empatia i człowieczeństwo.

(20) Zdecydowanie da się odczuć że Pani (...) angażuje się w problemy pacjenta $z$ e $\mathrm{m}$ patia jakiej brak już dzisiejszym medykom.

Wypowiedzi te wskazują na przekonanie pacjentów, że na podniesienie jakości opieki zdrowotnej wpłynęłaby większa humanizacja medycyny, uwzględniająca holistyczne, relacyjne podejście do chorego. Co ciekawe, w przykładach (19)-(20) autorzy zderzają współcześnie rozpowszechniony model podejścia do pacjenta (dzisiejszych medyków) $z$ wcześniejszym, choć zarazem nie wskazuja precyzyjnie momentu lub okresu z przeszłości, który postrzegają pozytywnie i kontrastuja $z$ zasadniczo negatywnie ocenianym 'teraz'. W przykładzie (19) lekarze definiowani przez zestaw cech doświadczenie, empatia $i$ człowieczeństwo 
określani sa jako ginacy gatunek. Jak wolno sądzić, obraz sterylnych białych wnętrz $i$ orchidei na [sic!] rejestracjach ma sugerować, że zdaniem autora tej wypowiedzi w opiece zdrowotnej kluczowy jest wymiar międzyludzki, a nie zewnętrzna otoczka, choćby wywołująca przyjemne wrażenia estetyczne.

Lista rzeczowników systematycznie tworzacych kolekcje $z$ jednostką empatia pokazuje, jakie inne walory lekarza pacjenci postrzegaja jako współwystępujace $z$ empatią. Nazwy tych cech i postaw wymieniam w kolejności, w której pojawiły się w narzędziu Word Sketch dla Sketch Engine, tj. ułożone rankingowo, według liczby statystycznie istotnych współwystapień w analizowanym korpusie. ${ }^{9}$

Tabela 3. Rzeczowniki tworzące kolekcje z jednostka EMPATIA (według liczby współwystąpień; źródło: Sketch Engine)

\begin{tabular}{|l|l|}
\hline 1) PROFESJONALIZM & 2) ZAANGAŻOWANIE \\
\hline 3) CIERPLIWOŚĆ & 4) ZROZUMIENIE \\
\hline 5) FACHOWOŚĆ & 6) SPOKÓJ \\
\hline 7) DELIKATNOŚĆ & 8) WIEDZA \\
\hline 9) WSPARCIE & 10) DOŚWIADCZENIE \\
\hline 11) ŻYCZLIWOŚĆ & 12) SERDECZNOŚĆ \\
\hline 13) CIEPŁO & 14) WRAŻLIWOŚĆ \\
\hline 15) TAKT & 16) POGODA DUCHA \\
\hline 17) KOMPETENCJA & 18) OTWARTOŚĆ \\
\hline 19) SZACUNEK & 20) KONTAKT \\
\hline
\end{tabular}

Rysunek 1. Wizualizacja najczęstszych kolekcji rzeczownika EMPATIA (żródło: Sketch Engine)

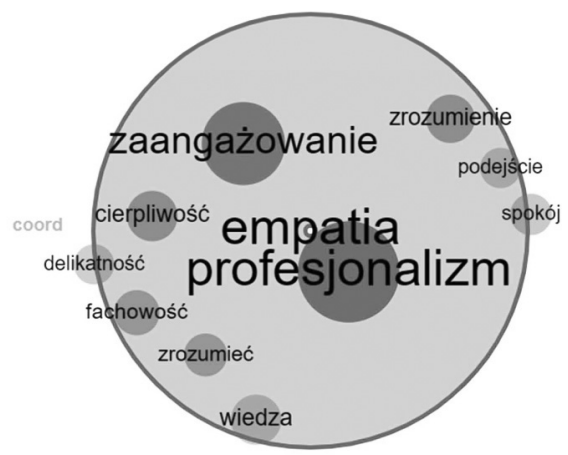

${ }_{9}$ Po koniecznych drobnych korektach dotyczacych lematyzacji. 
Dość szerokie spektrum towarzyszacych empatii nazw cech i postaw lekarza można spróbować uporządkować poprzez wskazanie wyłaniających się w tym zbiorze kilku mniejszych zespołów słowno-pojęciowych, np.:

1. wiedza i kompetencje specjalistyczne: profesjonalizm, fachowość, wiedza, doświadczenie, kompetencja;

2. umiejęt ności interpersonaln e: zrozumienie, życzliwość, serdeczność, ciepło, takt, otwartość, kontakt;

3. podejście do pa cjenta: zaangażowanie, cierpliwość, wsparcie, szacunek;

4. cechy osobowości i charakterystyka zachowania: spokój, delikatność, wrażliwość, pogoda ducha.

Empatia, jak wskazuje dotychczasowa literatura przedmiotu, jest zjawiskiem wieloaspektowym, intelektualno-emocjonalno-behawioralnym. Takie szerokie rozumienie na użytek psychologii społecznej proponuje m.in. Mark Davis:

Empatia została zdefiniowana szeroko, jako zespół konstrukcji teoretycznych, które dotyczą reakcji pojedynczego człowieka na doświadczenia innych. (...) typowy „epizod” empatyczny przebiega w następujący sposób: osoba obserwatora styka się w jakiś sposób z obserwowanym i następuje pewien rodzaj reakcji ze strony obserwatora (poznawcza, afektywna i/lub behawioralna) [Davis 1999, 23].

Ze względu na to, jaki typ reakcji subiektu dominuje w odpowiedzi na sytuację drugiej osoby, wyróżnia się zwykle e m pa ti ę e mo cjo n aln ą (polegająca na uczuciowej reakcji subiektu na przeżycia innej osoby, niekiedy prowadzi to do przeżywania jakościowo podobnych stanów emocjonalnych) oraz e m patię poznaw c za (zwiazana z przyjmowaniem przez subiekt perspektywy drugiej osoby, rozumieniem jej stanów wewnętrznych, m.in. uczuć, reakcji). Warto podkreślić, że opis empatycznego lekarza wyłaniający się $z$ opinii pacjentów to opis osoby, która jest postrzegana przez pryzmat swojego zachowania, w szczególności komunikacyjnego - swojej odpowiedzi na problem, z którym przychodzi chory. W zebranym korpusie nie pojawiają się świadectwa pacjentów opisujące to, w jaki sposób (w ich interpretacji) lekarz utożsamił się z nimi emocjonalnie, pacjenci nie koncentruja się na tym, co sam lekarz czuje ${ }^{10}-$ nie

$10 \mathrm{~W}$ typowym dla polszczyzny językowym obrazie empatii charakterystyczne jest także i to, że - choć w pewnych warunkach empatia może być opisywana jako recyprokalna (np. wzajemna empatia) - podstawowy wymiar relacji między subiektem empatii a jej obiektem jest jednokierunkowy. Zdecydowanie silniej utrwalone językowo jest myślenie o empatii lekarzy względem pacjentów czy nauczycieli wobec uczniów niż odwrotnie. Empatii oczekujemy bowiem typowo od ludzi, którzy zawodowo stykają się $z$ rozmaitymi trudnymi sytuacjami życiowymi. Literatura poświęcona empatii osób pracujących w zawodach medycznych lub studentów przygotowujacych się do takiej pracy przyrasta lawinowo i omówienie nawet najważniejszych prac zdecydowanie przerosłoby ramy artykułu. Nie 
wydaje się więc, aby oczekiwali od niego empatii emocjonalnej. Liczą natomiast przede wszystkim na empatię poznawcza manifestujaca się w zachowaniu lekarza: zrozumienie przez lekarza ich sytuacji, uszanowanie ich przeżyć oraz adekwatne wsparcie emocjonalne towarzyszace fachowej pomocy medycznej. Obserwację tę potwierdza ogląd najczęstszych połączeń rzeczownika empatia z czasownikami. Choć w polszczyźnie ogólnej dysponujemy kolokacjami odczuwać / czuć / poczuć empatię, ${ }^{11}$ które ujmuja empatię $z$ perspektywy jej subiektu, w moim korpusie dominują połączenia wykazać / wykazywać empatie, wykazać / wykazywać się empatia, okazać / okazywać empatię, cechować się empatia, wyróżniać się empatia, co nie dziwi, ponieważ wyspecjalizowały się one raczej w kodowaniu interpretacji budowanej $z$ perspektywy obiektu doświadczajacego empatii lub $z$ perspektywy zewnętrznego obserwatora relacji.

\section{3. „BYLA PRZESTRZEŃ DO ROZMOWY”. EMPATIA W KOMUNIKACJI LEKARZ - PACJENT}

Liczna grupa przykładów zgromadzonych w moim korpusie poświadcza ścisły związek między postrzeganą empatycznością lekarza a jego kompetencjami komunikacyjnymi.

Pacjenci zwracaja przede wszystkim uwagę na to, że czują się wysłuchani przez lekarza, który poświęca im uwagę, pozwala się wypowiedzieć i stara się zrozumieć ich sytuację. Por.:

(21) No i, co jest najważniejsze, to ogromne zaangażowanie w leczenie mojego schorzenia, poświęcenie ogromnej ilości uwagi i takie prawdziwe wsłuchanie się i wczucie w to, co mówię.

(22) Cudowna Pani, pełna empatii i pozytywnej energii! Słucha pacjenta i potrafi zrozumieć, co w tych czasach nie zdarza się jakoś często.

(23) Z uwaga słucha i wyczuwa się [sic!] w sytuację pacjenta, do każdego podchodzi indywidualnie.

(24) Już na pierwszej wizycie okazało się, że Pani doktor jest nie tylko bardzo dobrym fachowcem, ale i przemiła, pełną empatii osobą. Pani doktor przede ws zystkim dokładnie mnie wysłuchała, zrobiła szczegółowe badania i zaproponowała leczenie, które okazało się strzałem w dziesiątkę.

(25) Rzadko się zdarza tak kontaktowy lekarz. Nie mam wrażenia, że rozmawiam $z$ komputerem tylko $z$ fachowcem, który słucha i wszystko wyjaśnia. Długo szukałam takiej opieki.

napotkałam jednak dotą opracowania, w którym poruszono by kwestię kompetencji komunikacyjnej w zakresie empatii u pacjentów. Odpowiedzialność za budowanie relacji terapeutycznej, za kształt komunikacji i za umiejętne zarzadzanie nia składana jest tym samym (przede wszystkim lub nawet wyłącznie) na barki lekarza.

$11 \mathrm{Na}$ liście czasownikowych kolokatów empatii w NKJP odczuwać sytuuje się na pierwszej pozycji. 
Na nieodzowność aktywnego słuchania wypowiedzi pacjenta - jego opowieści o chorobie i chorowaniu - zwraca uwage nurt medycyny narracyjnej, w którym przyjmuje się, że:

(...) wypowiedzi osób chorych pozwalają im samym uporządkować sytuację, w której się znajduja, a lekarzom (oraz innym osobom sprawującym opiekę medyczną nad pacjentem) umożliwiaja poznanie wielu aspektów fizycznej i psychicznej kondycji pacjenta jako indywidualnej jednostki, w atmosferze bliskości i zaufania [Chojnacka-Kuraś 2019, 74].

Poza stworzeniem pacjentom możliwości wypowiedzenia się i aktywnym słuchaniem lekarz cechujący się empatia zwraca uwage na klarowne wytłumaczenie im przebiegu choroby, procedur medycznych lub działania leków. Por.:

(26) (...) opowiada co się dzieje, wszystko wyjaśnia, gdzie leżą mięśniaki, co powoduja, co może się dziać dalej. Pani Doktor jest pełna empatii.

(27) Przyjazna atmosfera plus tłu maczenie co robi - jak dla mnie rewelacja i na pewno nie zmienię już dentysty. Osoba pełna empatii i zaangażowania.

(28) Wykazuje się niezwykle dużą empatią i wrażliwością oraz w yja ś n i a s p o s ób leczenia bardzo szczegółowo, tak że wychodzi się z gabinetu bez krążacego nad głowa znaku zapytania. Kontaktzdoktorem na bardzo wysokim poziomie.

(29) Pan Doktor dokładnie opisał przebieg zabiegu, aw jego trakcie wykazał się dużą empatią i zrozumieniem. Profesjonalne podejście i duża wiedza, a także poczucie zaopiekowania.

(30) Pani Doktor zawsze $z$ uwaga analizuje każdą kwestię, wykazuje ogromną empatię wobec pacjenta. Dokładnie tłumaczy działanie przepisanych leków.

(31) Potrafi przekazać informacje w sposób klarowny i zrozumiały dla pacjenta. (...) Zawsze podchodzi do pacjenta $z$ empatia posiada pokłady cierpliwości (...).

Pacjenci, którzy nie mają wiedzy specjalistycznej, dzięki uzyskanym od lekarza informacjom czuja się traktowani podmiotowo. Szczególnie cenia to, że lekarz poświęca czas na wysłuchanie ich pytań i rozwianie wątpliwości:

(32) Doktor to życzliwy człowiek o dużej empatii do pacjenta $z$ wielką wolą niesienia pomocy chorym. Stara się w sposób przystępny zaproponować i wyjaśnić proces leczenia traktujac w rozmowie chorego jak partnera. Jestem pod wrażeniem takiego podejścia do pacjenta.

(33) Wizyta bardzo merytoryczna, a do tego pełna empatii, zrozumienia i ponadprzeciętnej komunikacji. Pan doktor szczegółowo wyjaśnił mi plan działania oraz kilkakrotnie i cierpliwie odpowiadał na moje pytania.

(34) W moim przypadku wykazał się ogromną empatią i fachowością. O d p o w i a d ał na każde moje pytania mimo, że dla innych lekarzy mogły by się okazać śmieszne.

(35) Każda minuta wizyty w pełni wykorzystana, odpowiedzi i wyjaśnienia na pytania czytelne, zrozumiałe. (...) również 
chciałabym polecić każdemu kto szuka wsparcia, zrozumienia, empatii, motywacji, akceptacji, szczerości, kompetencji.

(36) Szczegółowe wyjaśnienie problemu i cierpliwe rozwianie wszelakich wa t pliw ości. Komunikatywność w rozmowie.

Poważne, partnerskie traktowanie pacjenta przejawia się w tym wypadku w świadomości lekarza, że chory nie ma pełnej wiedzy, że towarzyszą mu wątpliwości (które niekiedy boi się wypowiedzieć, żeby się nie ośmieszyć), a przedstawienie pełnego obrazu sytuacji może sprawić, że pacjent będzie bardziej świadomie podejmował decyzje oraz będzie bardziej chętny do współpracy. Pacjenci wielokrotnie powtarzają, że kontakt $z$ lekarzem cechującym się empatią pozwala im zredukować strach i stres towarzyszacy chorowaniu (własnemu czy bliskiej osoby). Lekarz, który potrafi wyczuć stan emocjonalny pacjenta, może też skutecznie odpowiedzieć na towarzyszacy choremu niepokój, por.:

(37) Prowadziła moją drugą udaną ciążę (pierwsze poronienie). Miała m w s o bi e wiele strachu, niepewności, pytań. Pani Doktor była pełna empatii, wyrozumiała.

(38) Wizyta u Pana Doktora to czysta przyjemność komunikacja zaangażowanie, empatia, a przede wszystkim punktualność i umiejętność przekazania informacji zestresowanej kobiecie powoduja ze napięcie $z$ nika.

(39) Wszystko wyjaśnia szczegółowo, zawsze wychodzę z gabinetu świadoma, bez jakiegokolwiek niepokoju.

(40) Doktor (...) z pełna empatia podeszła do wystraszonego $\mathrm{d} z$ i e c ka i wszystko szczegółowo opowiadała co w danym momencie będzie robiła.

(41) Od niepamiętnych czasów moja Babcia nie była tak zaopiekowana. Pani Doktor w sposób rzeczowy, $z$ dużą empatią pochyliła się nad starszą schorowaną osobą zlecając wiele badań, które pozwolą wyjaśnić watpliwości dotyczące stanu nerek mojej Babci. Jednocześnie nie narażając jej na niebezpieczeństwo ze względu na ich inwazyjność. Serdecznie dziękuję za zrozumienie mnie jako przestraszonej wnuczki z powodu zleconego przez innego lekarza TK $z$ kontrastem.

Autorzy opinii zwracaja także uwage na sposób, w jaki lekarz prowadzi wywiad i w jaki sposób zarządza dialogiem z pacjentem, aby uzyskać potrzebne informacje.

(42) Pozwolił mi się wypowiedzieć i kierował tak rozmowa aby uzyskać ode mnie konkretne informacje które później posłużyły mu do pozostawienia diagnozy.

(43) Jego podejście do pacjentki było bardzo profesjonalne: $z$ jednej strony - lata doświadczeń zagwarantowały precyzyjną chirurgię i trafną ocenę medyczną, $z$ drugiej strony-merytoryczna rozmowa i empatia. Lekarzodpowiada na każde pytanie i spogląda na chorobę z każdego punktu wi d z e n i a. Ten spokój i duża wrażliwość wpływa na każdego jak balsam. 
Istotne w przebiegu rozmowy okazuja się nie tylko werbalne zachowania lekarza, ale także sfera niewerbalna, np. postawa ciała lub tembr głosu, który budzi zaufanie i daje pacjentowi poczucie bezpieczeństwa:

(44) Na samym wstępie pragnę zaznaczyć, że to jeden $z$ gabinetów i jedyny lekarz który zarówno pod względem kompetencjijak i tak pozornie nieistotnych rzeczy jak barwa głosu przekonał mnie do wykonania wielu skomplikowanych zabiegów, które jeśli chodzi o podjęcie decyzji nie są łatwe a co dopiero ich realizację. Wizyty odbywaja się w niesamowitej atmosferze pełnej empatii, spokoju, i poczucia bezpieczeństwa jednocześnie nie ujmując ogromnej fachowości i umiejętności Pana Doktora.

(45) Pani doktor budzi zaufanie ciepłym głose m oraz dużym zaangażowaniem $z$ jakim podchodzi do pacjenta.

(46) Pani Doktor bardzo miła, rzeczowa, s w o im głose m i postaw ą potrafiąca uspokoić nawet najbardziej cierpiącego pacjenta...

W ostatnich latach wiele uwagi poświęca się niewerbalnym aspektom komunikacji lekarz - pacjent [zob. np. Riess, Kraft-Todd 2014; Martin, DiMatteo 2013]. Poza tonem głosu, wskazanym w cytowanych przykładach, istotny jest kontakt wzrokowy, gesty mimiczne, postawa ciała przy rozmowie, a także wszelkie niewerbalne sygnały przeżyć emocjonalnych samego lekarza, które moga wpływać na kształt dialogu z pacjentem, jeśli nie sa poddane świadomej kontroli.

Przykłady negatywnych opinii pokazuja z kolei, że brak rozmowy, brak interakcji z pacjentem i zdawkowe odpowiedzi wpływaja na postrzeganie lekarza jako niezaangażowanego:

(47) Pani (...) odeszła od komputera tylko na chwilę, aby zajrzeć do buzi córki, ale nawet nie przekazała nam żadnego w tej kwestii komentarza. Sama musiałam dopytać (...) idostaliśmy jedynie w odpowiedzi kiwanie głowa.

Ważny dla pacjentów jest także poświęcony im czas - to, że lekarz znajduje czas na spokojna rozmowę i odpowiedzi na pytania, nie spieszy się:

(48) Bardzo dobry kontakt, empatia ale jednocześnie konkretne wskazówki, b e z po ś pi e c hu, była przestrzeń do rozmowy.

(49) Pełen profesjonalizm. Czułam się zaopiekowana. Bardzo dokładnie analizuje badania. Tłumaczy zrozumiałym językiem, nie spieszy się.

(50) Miła, empatyczna, wszystko szczegółowo wyjaśniła. Co ważne, podeszła do mnie holistycznie - a to niestety nie jest takie oczywiste u większości lekarzy. Czułam od Pani Doktor zainteresowanie i zaangażowanie, nie odczułam presji czas u ani chęci „pozbycia się" pacjenta z gabinetu. Jestem bardzo zadowolona $z$ wizyty - rzadko trafiam na tak empatycznych i kompetentnych lekarzy :)

Brak pośpiechu przy wizycie i zbudowanie przestrzeni dialogu ściśle związane sa $z$ kolejną kwestia, którą chciałabym poruszyć $-z$ indywidualizacja podejścia do pacjenta. 


\section{4. „TYLKO KOLEJNY PRZYPADEK”. INDYWIDUALNE PODEJŚCIE DO PACJENTA JAKO SYGNAE EMPATII LEKARZA}

Jak wskazuje przytoczona wcześniej definicja M.H. Davisa, empatia zakłada wymiar relacyjny [zob. także Falkowska, w druku]. Odzwierciedla się to w składniowych właściwościach rzeczownika empatia, który łączy się typowo $z$ lewostronnym argumentem odnoszącym się do subiektu empatii oraz $z$ prawostronnym argumentem w postaci frazy nominalnej wprowadzanej przyimkiem (np. dla, wobec, względem). Obydwa argumenty w najbardziej typowych realizacjach tekstowych wypełniane sa przez nazwy osobowe.

Autorzy wykorzystanych przeze mnie opinii daja wyraz przekonaniu, że podejście empatycznych lekarzy do chorych jest zindywidualizowane. Wizyta u takiego specjalisty pozostawia wrażenie, że pacjent traktowany jest podmiotowo, że lekarz chce leczyć daną osobę, a nie tylko kolejny przypadek choroby, por.:

(51) (...) inni myślę mogliby się od Pana Doktora uczyć empatii i bu dow a ni a re lacji $z$ pacjętka [sic!].

(52) Indywidualne traktowanie każdej osoby, profesjonalne podejście do pacjenta, olbrzymia empatia, poczucie bezpieczeństwa.

Jak twierdza S. Krukowska i in. [2019], metonimiczne zastapienie nazwy osoby chorej nazwa choroby jest typowa cechą socjolektu lekarskiego, w oczywisty sposób służąca ekonomizacji komunikacji wewnątrzśrodowiskowej i zwiększeniu jej efektywności, ${ }^{12}$ por.:

W środowiskowym zastosowaniu jednostka chorobowa lub jej objaw (...) bądź też chora część ciała (...) przypisane sa do pacjenta i określaja niejako jego samego. (...) We wspomnianych oddziałach szpitalnych można zatem usłyszeć sformułowania, takie jak: Gdzie leży ta głowa? - pytanie dotyczy 'pacjenta z urazem głowy', Przywieźli zawał! - komunikat o konieczności podjęcia akcji ratunkowej, gdyż karetka przywieziono chorego ze stwierdzonym zawałem mięśnia sercowego, Wymioty na korytarzu. - informacja o wystapieniu konkretnych objawów u pacjenta czekającego na przyjęcie przez lekarza [Krukowska i in. 2019, 156].

Z perspektywy pacjenta jednak taki zabieg językowy może być postrzegany jako uprzedmiotowienie - sprowadzenie osoby do kolejnego przypadku choroby. Pacjenci czuja wówczas, że lekarz nie koncentruje się na ich indywidualnej historii chorowania, por.:

(53) Przede wszystkim nie traktuje pacjentek jak „kolejny przypadek" i nie bagatelizuje problemów. Wysłuchuje każdej watpliwości,

12 O funkcjach metonimii w leksyce socjolektalnej pisze także A. Suchodolska [2016]. 
odpowiada na pytania, dokładnie wszystko wyjaśnia $z$ wielką empatią. Poświęca pacjentkom dużo czasu.

(54) Przy pierwszej wizycie okazana została mi empatia, nie czułam się „kolejnym przypadkiem z problemem”, natomiast czułam, że terapeuta mi współczuje.

Takiemu właśnie poczuciu uprzedmiotowienia (sprowadzenia do $n u-$ merka $w$ kolejce) i frustracji wynikajacej z postrzegania lekarza jako niewystarczająco empatycznego dała wyraz autorka negatywnej opinii, por.:

(55) Zostałam zostawiona sama sobie. Czułam sie jak jedna z wielu, jak numerek w kolejce, a nie pacjentka, ktora potrzebuje pomocy. Zero empatii, zero troski.

Poza kompetencjami językoznawcy pozostaje stwierdzenie, czy brak indywidualnego podejścia do pacjenta spostrzegany u niektórych lekarzy wynika $z$ ich niedostatecznych umiejętności komunikacyjnych, czy może $z$ trudnych warunków pracy specjalistów, którzy nie zawsze moga pozwolić sobie na tak długie wizyty i pogłębione dialogi, jakich oczekiwaliby i potrzebowaliby chorzy.

\section{PODSUMOWANIE}

Przedstawiona w niniejszej pracy analiza o charakterze korpusowym miała na celu wskazanie, jakie cechy przypisuja pacjenci lekarzowi, którego określaja jako empatycznego, i jakie zachowania wiążą $z$ okazywaniem przez lekarza empatii. Uwzględnienie perspektywy chorego jest o tyle ważne, że postrzegany przez pacjenta poziom empatii lekarza może nie pokrywać się $z$ tym, jaki przypisuje sobie sam lekarz, $\mathrm{np}$. w procedurze autoewaluacji. Obecnie poza eksperymentalnymi metodami badania poziomu empatii lekarza dysponujemy także ustandaryzowanymi testami pozwalającymi pacjentowi ocenić empatię lekarza. Najlepiej znany jest krótki kwestionariusz Skala Jefferson percepcji empatii lekarza przez pacjenta (Jefferson Scale of Patient's Perceptions of Physician Empathy) [Kane i in. 2007], w którym respondenci mają za pomoca skali Likerta ocenić m.in., czy ich zdaniem lekarz rozumie ich emocje, uczucia i troski, czy potrafi spojrzeć na problem $z$ perspektywy pacjenta, czy interesuje się szerszym kontekstem życia pacjenta (np. sytuacją rodzinna). K.M. Glaser i in. [2007] potwierdzili, że autoewaluacja lekarza skorelowana jest $z$ ocena poziomu empatii dokonywana przez pacjenta. M.O. Bernardo i in. [2018] stwierdzili z kolei, że samoocena lekarza nie do końca pokrywa się $z$ ocena pacjenta i zasugerowali, aby modele kształcenia empatii klinicznej w większym stopniu uwzględniały uwagi pacjentów. Jest to o tyle ważne, że pacjenci znaczaco bardziej skłonni sa do podporządkowania się zaleceniom lekarzy, których po- 
strzegaja jako empatycznych [Hojat i in 2010], a niedostateczna empatia lekarza wobec pacjenta

(...) wpływa na pogorszenie ich wzajemnych relacji, a w konsekwencji - na większą liczbę skarg, co $z$ kolei obniża satysfakcję lekarza $z$ pracy i nasila proces wypalenia zawodowego [Janczukowicz 2014, 100].

Przeprowadzona analiza oparta jest na konkretnym korpusie, a wszystkie obserwacje i wnioski dotycza dość ograniczonego zbioru danych. Warto jednak postulować dalsze badania nad sposobem rozumienia wyrażenia empatia zarówno przez lekarzy, jak i przez pacjentów, aby upewnić się, że treści, które dwie grupy użytkowników języka wiążą $z$ tym słowem, sa wystarczająco zbieżne, aby zapewnić skuteczne porozumiewanie się.

\section{Bibliografia}

W.F. Baile, R. Buckman, R. Lenzi, G. Glober, E.A. Beale, A.P. Kudelka, 2000, SPIKES - a six-step protocol for delivering bad news: application to the patient with cancer, „The Oncologist” 5(4), s. 302-311.

B. Baranowska, A. Doroszewska, 2018, Porozumienie bez przemocy. Jak wykorzystać empatyczna komunikacje na sali porodowej?, „Zeszyty Naukowe Ochrony Zdrowia. Zdrowie Publiczne i Zarzadzanie" 16(4), s. 241-246.

J. Bartmiński, S. Niebrzegowska-Bartmińska, 2009, Tekstologia, Warszawa.

M.O. Bernardo, D. Cecílio-Fernandes, P. Costa, T.A. Quince, M.J. Costa, M.A. Carvalho-Filho, 2018, Physicians' self-assessed empathy levels do not correlate with patients' assessments, „PLoS ONE” 13(5), s. 1-13; https://doi. org/10.1371/journal.pone.0198488

M. Chojnacka-Kuraś, 2019, Medycyna narracyjna $z$ perspektywy lingwistyki i poetyki kognitywnej [w:] M. Chojnacka-Kuraś (red.), Medycyna narracyjna. Opowieści o doświadczeniu choroby $w$ perspektywie medycznej $i$ humanistycznej, Warszawa, s. 72-93.

M.H. Davis, 1999, Empatia. O umiejętności współodczuwania, tłum. J. Kubiak, Gdańsk.

J. Doroszewski, M. Kulus, A. Markowski, M. Kosowicz, M. Kulpa, S. Świstak-Sawa, J. Meder (red.), 2014, Porozumienie z pacjentem. Relacje i komunikacja, Warszawa.

A. Dziadel, O. Pokorska, B. Polityńska, 2019, Ogólne zasady komunikacji z pacjentem [w:] E. Krajewska-Kułak, A. Guzowski, G. Bejda, A. Lankau (red.), Kontekst „Inności” w komunikacji interpersonalnej, Białystok, s. 77-86.

M. Falkowska, Konstruowanie relacji międzyosobowych w znaczeniach wybranych nazw allocentrycznych stanów emocjonalnych i postaw: perspektywa jezykoznawcza [w druku].

A.S. Franzke, A. Bechmann, M. Zimmer, Ch. Ess, 2020, Internet Research: Ethical Guidelines 3.0.; https://aoir.org/reports/ethics3.pdf

K.M. Glaser, F.W. Markham, H.M. Adler, P.R. McManus, M. Hojat, 2007, Relationships between scores on the Jefferson Scale of physician empathy, patient 
perceptions of physician empathy, and humanistic approaches to patient care: a validity study, „Department of Psychiatry and Human Behavior Faculty Papers", Paper 58; https://jdc.jefferson.edu/phbfp/58

M. Hojat, D.Z. Louis, K. Maxwell, F. Markham, R. Wender, J.S. Gonnella, 2010, Patient perceptions of physician empathy, satisfaction with physician, interpersonal trust, and compliance, „International Journal of Medical Education" 1, s. 83-87; https://doi.org/10.5116/ijme.4d00.b701

J. Janczukowicz, 2014, Empatia jako zasadnicza kompetencja współczesnego lekarza [w:] J. Janczukowicz (red.), Profesjonalizm lekarski, Warszawa, s. 94-102.

A. Jankowska, 2014, Komunikacja medyczna $w$ onkologii dziecięcej. Przekazywanie informacji o rozpoznaniu choroby nowotworowej, „Psychoonkologia” 4, s. $123-127$.

G.C. Kane, J.L. Gotto, S. West, M. Hojat, S. Mangione, 2007, Jefferson Scale of Patient's Perceptions of Physician Empathy: preliminary psychometric data, „Croatian medical journal” 48(1), s. 81-86.

A. Kilgarriff, V. Baisa, J. Bušta, M. Jakubiček, V. Kovář, J. Michelfeit, P. Rychlý, V. Suchomel, 2014, The Sketch Engine: ten years on, „Lexicography” 1, s. $7-36$.

J. Kliszcz, 2015, Empatia i jej wpływ na relacje terapeuta-pacjent [w:] J. Kliszcz, Psychologia dla fizjoterapeutów i masażystów. Wybrane zagadnienia, Warszawa, s. 116-131.

S. Królak, 2017, Empathetic doctor-the role and the significance of the empathy in the doctor - patient relation, "Zdrowie Publiczne i Zarzadzanie” 15(4), s. 288-298; https://doi.org/10.4467/20842627OZ.17.031.8285

S. Krukowska, K. Koszela, M. Woldańska-Okońska, 2019, Communicatio medica, czyli specyfika porozumiewania sie intermedycznego, „Prace Filologiczne" 73, s. 153-163, https://doi.org/10.32798/pf.489

L.R. Martin, M.R. DiMatteo, 2013, Clinical interactions [w:] J.A. Hall, M.L. Knapp (red.), Nonverbal Communication, Berlin, s. 833-858.

H. Riess, G. Kraft-Todd, 2014, E.M.P.A.T.H.Y: a tool to enhance nonverbal communication between clinicians and their patients, „Academic Medicine” 89(8), s. 1108-1112; https://doi.org/10.1097/ACM.0000000000000287

M. Rosenberg, P. Molho, 1998, Nonviolent (empathic) communication for health care providers, „Haemophilia” 4 (4), s. 335-340.

A. Suchodolska, 2016, Cechy polskich, rosyjskich i angielskich profesjolektów $i$ socjolektów medycznych na podstawie badań ankietowych, „Prace Filologiczne" 68, s. 357-373.

E. Wilczek-Rużyczka, 2017, Empatia pracowników medycznych, Warszawa.

M. Woźniak, 2021, Leksykalne środki wartościowania w opiniach na temat lekarzy na portalu ZnanyLekarz.pl, niepublikowana praca magisterska.

E. Ziółkowska-Rudowicz, A. Kładna, 2014, Empatia w medycynie, Szczecin. 


\section{What is an empathetic doctor like? The view of doctor's empathy in opinions published on the ZnanyLekarz.pl web portal}

\section{Summary}

The paper provides a corpus-based semantic analysis of patients' opinions on doctors published on the ZnanyLekarz.pl web portal. The analysis is aimed at depicting the medical professionals' traits and behaviours that patients interpret as expressions of empathy. The findings suggest that while patients value the doctor's empathy, they perceive it as a relatively rare quality in doctors. The sphere where empathy manifests itself to the greatest extent is undoubtedly doctor-patient communication: unhurried interview, active listening, explaining the course of the necessary medical procedures, responding to the patient's questions, showing emotional support. Although the findings coincide with the recommendations found in the communication guides addressed to doctors, taking into account the perspective of the patient is necessary, since patients' perception of empathy may not correlate perfectly with doctors' self-assessment.

Keywords: empathy - doctor-patient communication - communicative competence - corpus.

Adj. Monika Czarnecka 